\title{
Comparison of Viral Agents and Vitamin D Levels in Children with Acute Bronchiolitis Infection
}

\author{
Akut Bronşiyolit Enfeksiyonu Olan Çocuklarda Viral Etkenler ile D Vitamin \\ Düzeyinin Karşılaştırılması
}

\author{
Zahide Yalaki', Medine Ayşin Taşar', Harun Öney', Arife Uslu Gökçeoğlu' \\ ${ }^{1}$ Clinic of Pediatric, Ankara Training and Research Hospital, Ankara, Turkey
}

Cite this article as: Yalaki Z, Taşar MA, Öney H, Uslu Gökçeoğlu A. Comparison of viral agents and vitamin D levels in children with acute bronchiolitis infection. J Pediatr Inf 2019;13(1):e14-e20

\section{Abstract}

Objective: The aim of this study was to determine the vitamin D level and prognostic relationship with viral agents causing acute bronchiolitis.

Material and Methods: Files of the patients who were hospitalized with the diagnosis of acute bronchiolitis in the pediatric service and intensive care unit of Ankara Training and Research Hospital were reviewed retrospectively. Patients were classified as mild, moderate or severe according to clinical evaluation. Serum $25(\mathrm{OH})$ vitamin D levels were classified as $<20 \mathrm{ng} / \mathrm{mL}$ deficient, $20-30 \mathrm{ng} / \mathrm{mL}$ insufficient, and $>30 \mathrm{ng} /$ $\mathrm{mL}$ normal.

Results: Median age of 130 patients was 8 months (1-108) and $60.8 \%$ were male. $69.2 \%$ of the patients were the citizens of the Republic of Turkey while $30.8 \%$ were refugees. $28.5 \%$ of the patients had mild, $30 \%$ had moderate, and $41.5 \%$ had severe scores. High flow oxygen therapy was applied to $56.9 \%$ of the patients and oseltamivir treatment was given to $50.8 \%$ of the patients. $26.9 \%$ of the patients were observed in intensive care and $3.8 \%$ were observed in mechanical ventilator. Respiratory syncytial virus was detected in $55.3 \%$ of nasopharyngeal swab specimens. Vitamin D deficiency was found in $36.9 \%$ and vitamin D insufficiency was found in 33.8\% of the patients. Male patients who were citizens of the Republic of Turkey and who were given prophylactic vitamin $\mathrm{D}$ had significantly higher 25 $(\mathrm{OH})$ vitamin $D$ levels than other groups $(\mathrm{p}<0.05) .25(\mathrm{OH})$ vitamin D levels were found to be $21.9 \mathrm{ng} / \mathrm{mL}$ in patients with respiratory syncytial virus infection and $24.2 \mathrm{ng} / \mathrm{mL}$ in other viral swab samples $(p=0.058)$. Vitamin D levels were below normal in $70.3 \%$ of high-flow oxygen therapy patients and $71.2 \%$ of patients receiving oseltamivir treatment.
Öz

Giriş: Akut bronşiyolite neden olan viral etkenler ile $D$ vitamini düzeyi ve prognostik ilişkinin belirlenmesi amaçlanmıştır.

Gereç ve Yöntemler: Çalışmada Ankara Eğitim ve Araştırma Hastanesi Çocuk Servisi ve Yoğun Bakımında akut bronşiyolit tanısı ile yatırılan hastaların dosyaları geriye dönük olarak incelendi. Hastalar klinik değerlendirilmesine göre hafif-orta ve ağır olarak sınıflandırıldı. Serum $25(\mathrm{OH}) \mathrm{D}$ vitamin düzeyi $<20 \mathrm{ng} / \mathrm{mL}$ olan değerler $D$ vitamini eksikliği, 20-30 ng/ $\mathrm{mL}$ arasındaki değerler $D$ vitamini yetersizliği, $>30 \mathrm{ng} / \mathrm{mL}$ olan değerler ise normal olarak değerlendirildi.

Bulgular: D vitamini düzeylerine bakılan 130 hastanın yaş ortancası 8 ay (1-108) ve \%60.8'i erkek idi; hastaların \%69.2'sinin Türkiye Cumhuriyeti vatandaşı, \%30.8'inin mülteci olduğu saptandı. Hastaların $\% 28.5^{\prime} i$ hafif, \%30'u orta, \%415'i ağır şiddet skoruna sahipti. Hastaların \%56.9 'una yüksek akımlı oksijen tedavisi uygulandı ve $\% 50.8$ 'ine oseltamivir tedavisi verildi. Hastaların \%26.9'u yoğun bakımda, \%3.8'i mekanik ventilatörde izlendi. Nazofarengeal sürüntü örneklerinden $\% 55.3$ 'ünde respiratuar sinsityal virüs (RSV) saptandı. Hastaların \%36.9'unda D vitamini yetersizliği, \%33.8'inde D vitamini eksikliği saptandı. Erkeklerde, Türkiye Cumhuriyeti vatandaşı olanlarda ve profilaktik $D$ vitamini kullanmış olan hastalarda $25(\mathrm{OH}) \mathrm{D}$ vitamini düzeyi diğer gruba göre istatistiksel olarak daha yüksek saptandı $(p<0.05)$. RSV enfeksiyonu olanların $25(\mathrm{OH}) \mathrm{D}$ vitamin düzeyi $21.9 \mathrm{ng} / \mathrm{mL}$, diğer viral sürüntü örneklerinde ise $24.2 \mathrm{ng} / \mathrm{mL}$ olarak saptandı $(p=0.058)$. Yüksek akımlı oksijen tedavisi uygulanan hastaların \%70.3'ünde ve oseltamivir tedavisi alan hastaların \%71.2'inde D vitamin düzeyleri normalin altında idi.

Correspondence Address / Yazışma Adresi

Zahide Yalaki

Ankara Eğitim ve Araştırma Hastanesi,

Çocuk Sağlığı ve Hastalıkları Kliniği,

Ankara-Türkiye

E-mail: dr_zahide@yahoo.com 
Conclusion: Although there was no relationship between vitamin D levels and viral agents, $25(\mathrm{OH})$ vitamin D levels of patients with severe bronchiolitis, intensive care unit patients, and high flow oxygen therapy patients were found to be below normal. We think that $25(\mathrm{OH}) \mathrm{D}$ vitamin levels should be considered in children with acute bronchiolitis clinic and vitamin D treatment can be useful.

Keywords: Acute bronchiolitis, viral infection, $25(\mathrm{OH})$ vitamin D levels

\section{Introduction}

Lower respiratory tract infections (LRTI) (i.e. acute bronchiolitis, pneumonia, bronchopneumonia) seen frequently in childhood can cause significant levels of diseases and morbidity (1). There are many causes leading to the development of LRTI in children. Most frequently encountered causes include age $(<1$ year), preterm birth, low birth weight, chronic disease, nutrition disorders, not being breastfed, crowded life conditions, cigarette use in the family, and insufficient immunization (2).

The effect of vitamin D over calcium and bone metabolism is well known. In recent genetic and epidemiological studies, it has been put forth that vitamin D has a vital and complex role in the function and regulation of the immune system and in the defense of the host against respiratory tract infections (3-5). La-hydroxylase enzyme producing active vitamin $D$ and released by air way epithelia, alveolar macrophages, dendritic cells and lymphocytes show that active vitamin $D$ can be locally produced within the lungs (6). The effects of vitamin D within the lungs have been reported as follows: increasing antimicrobial peptides, particularly the production of cathelicidin in epithelial cells; rising the cytotoxic activity of natural killer cells and the formation of superoxide of monocytes; decreasing chemokine production; and the inhibition of dendritic cell activation $(5,6)$. The hypothesis claiming that the decrease in vitamin $D$ production due to the reduction in ultraviolet $B$ rays during winter months leads to the increase in the frequency of LRTI has been put forth $(6,7)$.

Viruses are the most common causes of respiratory tract infections in children. Although viral respiratory tract infections affect all age groups, they can cause recurrent infections seen within a year in early aged groups $(1,2)$. Respiratory syncytial virus (RSV), rhinovirus, influenza virus, coronavirus, parainfluenza virus, human metapneumovirus, adenovirus are the most commonly observed viruses leading to respiratory tract disorders $(8,9)$. RSV and influenza viruses responsible for hospital admittance in adult patients can lead to severe infections in children under the age of five $(10,11)$.

The relation between vitamin D and RSV and LRTI have been shown in the literature $(3,11)$. In this study, it was aimed to investigate the relation between vitamin $D$ and viral agents
Sonuç: D vitamini düzeyi ile viral etkenler arasında bir ilişki bulunmamasına rağmen ağır bronşiyolit kliniği olan, yoğun bakıma yatan ve yüksek akımlı oksijen tedavisi alan hastaların $25(\mathrm{OH})$ D vitamin düzeyleri, normalin altında saptanmıştır. Akut bronşiyolit kliniği olan çocuklarda $25(\mathrm{OH}) \mathrm{D}$ vitamin düzeyi bakılması ve gerekli hastalara $D$ vitamini tedavisinin yapılmasının faydalı olabileceğini düşünmekteyiz.

Anahtar Terimler: Akut bronşiyolit, viral enfeksiyon, $25(\mathrm{OH}) \mathrm{D}$ vitamin düzeyi

(RSV and other agents) causing LRTI in patients with acute bronchiolitis and also the relation between the level of vita$\min \mathrm{D}$ with the severity of the disease and the treatment implemented.

\section{Materials and Methods}

In this study, the files of the patients admitted to the pediatric service and the intensive care unit of Ankara Training and Research Hospital with a diagnosis of acute bronchiolitis between October 2017 and March 2018 were retrospectively reviewed. Demographics of the patients, month of referral, clinical and laboratory findings, hospitalization duration, whether the patients received high flow oxygen therapy and oseltamivir therapy or not, and the results of the nasopharyngeal swabs were recorded. Out of the children diagnosed with lower respiratory tract infection, those with preterm birth, low birth weight and chronic diseases, those receiving antibiotics, and those in whom no agent was detected in the nasopharyngeal swab and those without vitamin D results were excluded from the study. By retrospectively reviewing general polyclinic files, the control group included children without an active infection and chronic disease in the same age group, whose vitamin D level was tested for any other reason.

Patients were classified as mild, moderate and severe according to their clinical evaluation (8). Serum $25(\mathrm{OH})$ vitamin D levels of $<20 \mathrm{ng} / \mathrm{mL}$ were classified as Vitamin D deficient, 20$30 \mathrm{ng} / \mathrm{mL}$ as Vitamin D insufficient, and $>30 \mathrm{ng} / \mathrm{mL}$ as normal (12).

SPSS (Stastistical Package For Social Sciences) for Windows 20.0 was used for data analysis. Kolmogorov-Smirnov test was used to determine whether the distribution of continuous and discontinuous numerical variables was close to normal. Defining statistics were shown as median (minimum-maximum) for continuous and discontinuous numerical variables, and categorical variables were shown as case number and "\%". The significance of the difference between the groups in terms of median values was investigated by Mann-Whitney $U$ test. Categorical variables were evaluated by either Pearson`s Chi-square or Fisher's Exact $\mathrm{Chi}=$ Square test.

Approval from our hospital's ethical board was received for the study under the number 0058-599. 


\section{Results}

One hundred and thirty patients admitted to the pediatric service and intensive care unit of our hospital with the diagnosis of acute bronchiolitis and whose vitamin D levels were screened were included into the study. Sixty children were included into the control group. Median age of the patients was 8 months (1-108) and $60.8 \%(n=79)$ were male. Median age of the control group was 11 months (5-101) and 55\% were male. No significant difference was detected in terms of age and sex between the patient and control groups ( $p>0.05$ ). While $69.2 \%$ of the patients were citizens of the Republic of Turkey and $30.8 \%$ were refugees, $56.7 \%$ of the controls were citizens of the Republic of Turkey and $43.3 \%$ were refugees $(p=0.091)$ (Table 1).

Table 1. Demographics of the patients included into the study

\begin{tabular}{|c|c|c|}
\hline & $\mathbf{n}$ & $\%$ \\
\hline $\begin{array}{l}\text { Sex } \\
\text { Female } \\
\text { Male }\end{array}$ & $\begin{array}{l}51 \\
79 \\
\end{array}$ & $\begin{array}{l}39.2 \\
60.8\end{array}$ \\
\hline $\begin{array}{l}\text { Nationality } \\
\text { Republic of Turkey } \\
\text { Refugee }\end{array}$ & $\begin{array}{l}90 \\
40 \\
\end{array}$ & $\begin{array}{l}69.2 \\
30.8\end{array}$ \\
\hline $\begin{array}{l}\text { Date of referral (month) } \\
\text { October } \\
\text { November } \\
\text { December } \\
\text { January } \\
\text { February } \\
\text { March }\end{array}$ & $\begin{array}{c}12 \\
4 \\
0 \\
46 \\
46 \\
22 \\
\end{array}$ & $\begin{array}{c}9.2 \\
3.1 \\
0 \\
35.4 \\
35.4 \\
16.9 \\
\end{array}$ \\
\hline $\begin{array}{l}\text { Disease severity } \\
\text { Mild } \\
\text { Moderate } \\
\text { Severe }\end{array}$ & $\begin{array}{l}37 \\
39 \\
54\end{array}$ & $\begin{array}{c}28.5 \\
30 \\
41.5\end{array}$ \\
\hline $\begin{array}{l}\text { Number of attacks } \\
\text { First } \\
\text { Second } \\
\geq \text { Third }\end{array}$ & $\begin{array}{l}90 \\
18 \\
22\end{array}$ & $\begin{array}{l}69.2 \\
13.8 \\
16.9 \\
\end{array}$ \\
\hline $\begin{array}{l}\text { History of prophylactic vitamin D use } \\
\text { Yes } \\
\text { No }\end{array}$ & $\begin{array}{c}113 \\
17\end{array}$ & $\begin{array}{l}86.9 \\
13.1\end{array}$ \\
\hline $\begin{array}{l}\text { Viral swab results } \\
\text { RSV } \\
\text { Rhinovirus } \\
\text { Metapneumovirus } \\
\text { Multiple reproduction } \\
\text { Coronavirus } \\
\text { Parainfluenza virus } \\
\text { Bocavirus } \\
\text { Adenovirus } \\
\text { Influenzavirus }\end{array}$ & $\begin{array}{c}72 \\
14 \\
13 \\
9 \\
8 \\
5 \\
4 \\
3 \\
2\end{array}$ & $\begin{array}{c}55.3 \\
10.8 \\
10 \\
7 \\
6.1 \\
3.9 \\
3.1 \\
2.3 \\
1.5\end{array}$ \\
\hline $\begin{array}{l}25(\mathrm{OH}) \text { vitamin D level }(\mathrm{ng} / \mathrm{mL}) \\
<20 \\
20-30 \\
>30\end{array}$ & $\begin{array}{l}48 \\
44 \\
38\end{array}$ & $\begin{array}{l}36.9 \\
33.8 \\
29.2\end{array}$ \\
\hline
\end{tabular}

$28.5 \%$ of the patients had mild, $41.5 \%$ had moderate, and $41.5 \%$ had severe severity score. $86.9 \%$ of the patients $(n=$ 113) had used prophylactic vitamin $D$ under the age of 1 . Median hospitalization duration was 7 days (3-54). High flow oxygen therapy was given to $56.9 \%(n=74)$ of the patients and oseltamivir treatment to $50.8 \%(n=66) .26 .9 \%$ of the patients $(n=35)$ were followed in the intensive care unit and $3.8 \%$ in mechanical ventilation. RSV was seen in $55.3 \%$ of the nasopharyngeal swab specimens, rhinovirus in $10.7 \%$, multiple reproduction in $6.92 \%$ and influenza virus in $1.5 \%$ (Table 2 ).

While serum $25(\mathrm{OH})$ vitamin $\mathrm{D}$ median of the patients was found as $22.5 \mathrm{ng} / \mathrm{mL}$ (3-58.7), serum $25(\mathrm{OH})$ vitamin D median of the control group was $22.2 \mathrm{ng} / \mathrm{mL}$ (10-39.8). No significant difference in terms of $25(\mathrm{OH})$ Vitamin D levels between the patient and control groups was detected ( $p=0.746) .36 .9 \%$ of the patients $(n=48)$ had vitamin D deficiency, 33.8\% ( $n=$ 44) had vitamin $D$ insufficiency and only $29.2 \%(n=38)$ had vitamin $D$ sufficiency. In $70.7 \%$ of all patients $(n=92), 25(\mathrm{OH})$ vitamin D level was $<30 \mathrm{ng} / \mathrm{mL}$.

When factors affecting $25(\mathrm{OH})$ vitamin D levels in males, Turkish citizens and in patients who had used prophylactic vitamin $D, 25(\mathrm{OH})$ vitamin $D$ level was detected statistically higher as regards the other group $(p<0.05)$ (Table 2). A significant relation between the severity of the disease and $25(\mathrm{OH})$ vitamin $D$ level was not determined $(p=0.418)$.

Although a statistical relation was not found between the severity of the disease and vitamin $D$ levels being $<20 \mathrm{ng} / \mathrm{mL}$, 20-30 ng/mL and $>30 \mathrm{ng} / \mathrm{mL}$, vitamin D level was detected as $<30 \mathrm{ng} / \mathrm{mL}$ in $74 \%$ of the patients with severe $(n=40)$ and in $68.4 \%$ of the patients with mild-moderate disease severity scores $(p=0.438)$ (Table 3). Even though $25(\mathrm{OH})$ vitamin D level in $77.1 \%$ of the patients requiring intensive care $(n=27)$ and in $68.4 \%$ of the patients not requiring intensive care $(n=65)$ was, $<30 \mathrm{ng} / \mathrm{mL}$, a statistical difference was not found ( $p=0.332$ ).

While $25(\mathrm{OH})$ vitamin $D$ levels of the patients in the intensive care unit was $21.2 \mathrm{ng} / \mathrm{mL}$ (3.1-57.9), $25(\mathrm{OH})$ vitamin $D$ levels of the patients followed in the service was $23 \mathrm{ng} / \mathrm{mL}$ $(3-58.7)(p=0.071)$ (Table 2). A relation was not determined between low vitamin $D$ levels and number of attacks, hospitalization duration and high flow oxygen therapy ( $p>0.05$ ).

$25(\mathrm{OH})$ D vitamin D level of the patients with RSV infection was $21.9 \mathrm{ng} / \mathrm{mL}$ (3.09-58.7) and it was $24.2 \mathrm{ng} / \mathrm{mL}$ (3-57.9) in other viral swab specimens, and a statistical difference was not present $(p=0.058)$. Vitamin D deficiency was detected in $40.3 \%$ of the patients with RSV infection and vitamin D insufficiency in $36.1 \%$ of the patients ( $p=0.289$ ).

There was not a difference between the level of $25(\mathrm{OH})$ vitamin $D$ and the patients use of oseltamivir $(p=0.263)$ and high flow oxygen therapy intake $(p=0.272)$ (Table 2$)$. Howev- 
Table 2. $25(\mathrm{OH})$ vitamin D levels according to the demographics of the study group *

\begin{tabular}{|c|c|c|c|}
\hline & Median & Minimum-Maximum & $\mathbf{p}$ \\
\hline $\begin{array}{l}\text { Sex } \\
\text { Female } \\
\text { Male }\end{array}$ & $\begin{array}{l}20.0 \\
24.0\end{array}$ & $\begin{array}{l}3.0-50.4 \\
3.9-58.7\end{array}$ & 0.028 \\
\hline $\begin{array}{l}\text { Natinality } \\
\text { Reoublic of Turkey } \\
\text { Refugee }\end{array}$ & $\begin{array}{l}24.2 \\
17.4 \\
\end{array}$ & $\begin{array}{l}3.0-58.7 \\
3.1-57.9\end{array}$ & 0.001 \\
\hline $\begin{array}{l}\text { Disease severity } \\
\text { Mild } \\
\text { Moderate } \\
\text { Severe }\end{array}$ & $\begin{array}{l}23.0 \\
24.0 \\
22.0\end{array}$ & $\begin{array}{l}3.0-39.2 \\
3.8-50.4 \\
3.0-58.7\end{array}$ & 0.418 \\
\hline $\begin{array}{l}\text { Prophylactic vitamin D use } \\
\text { Yes } \\
\text { No }\end{array}$ & $\begin{array}{l}23.0 \\
16.0\end{array}$ & $\begin{array}{l}3.1-58.7 \\
3.0-31.0\end{array}$ & 0.001 \\
\hline $\begin{array}{l}\text { High flow oxygen therapy } \\
\text { Yes } \\
\text { No }\end{array}$ & $\begin{array}{l}23.0 \\
24.0\end{array}$ & $\begin{array}{l}3.1-58.7 \\
3.0-50.4\end{array}$ & 0.272 \\
\hline $\begin{array}{l}\text { Intensive care stay } \\
\text { Yes } \\
\text { No }\end{array}$ & $\begin{array}{l}21.2 \\
23.0\end{array}$ & $\begin{array}{l}3.1-57.9 \\
3.0-58.7\end{array}$ & 0.071 \\
\hline $\begin{array}{l}\text { Viral swab result } \\
\text { RSV } \\
\text { Other }\end{array}$ & $\begin{array}{l}21.9 \\
24.2\end{array}$ & $\begin{array}{l}3.1-58.7 \\
3.0-57.9\end{array}$ & 0.058 \\
\hline
\end{tabular}

Table 3. Evaluation of the demographics of the study group in terms of vitamin $D$ level

\begin{tabular}{|c|c|c|c|c|}
\hline & $<30 \mathrm{n}(\%)$ & $>30 \mathrm{n}(\%)$ & $\mathbf{p}$ & Odds ratio \\
\hline $\begin{array}{l}\text { Disease severity (n) } \\
\text { Mild-moderate (76) } \\
\text { Severe (54) }\end{array}$ & $\begin{array}{c}52(68.4) \\
40(74)\end{array}$ & $\begin{array}{c}24(31.6) \\
14(26)\end{array}$ & 0.438 & $0.591-3.364$ \\
\hline $\begin{array}{l}\text { High flow oxygen therapy (n) } \\
\text { Present (74) } \\
\text { Absent (56) }\end{array}$ & $\begin{array}{l}52(70.3) \\
40(71.5)\end{array}$ & $\begin{array}{l}22(29.7) \\
16(28.5)\end{array}$ & 0.886 & $0.472-2.272$ \\
\hline $\begin{array}{l}\text { Oseltamivir treatment }(\mathbf{n}) \\
\text { Present (66) } \\
\text { Absent (64) }\end{array}$ & $\begin{array}{l}47(71.2) \\
45(70.3)\end{array}$ & $\begin{array}{l}19(28.8) \\
19(29.7)\end{array}$ & 0.910 & $0.450-2.039$ \\
\hline $\begin{array}{l}\text { Intensive care necessity (n) } \\
\text { Present (35) } \\
\text { Absent (95) }\end{array}$ & $\begin{array}{l}27(77.1) \\
65(68.4)\end{array}$ & $\begin{array}{c}8(22.9) \\
30(31.6)\end{array}$ & 0.332 & $0.261-1.579$ \\
\hline $\begin{array}{l}\text { Viral swab(n) } \\
\text { RSV (72) } \\
\text { Other (58) }\end{array}$ & $\begin{array}{l}55(76.4) \\
37(63.8) \\
\end{array}$ & $\begin{array}{l}17(23.6) \\
21(36.2) \\
\end{array}$ & 0.117 & $0.856-3.939$ \\
\hline
\end{tabular}

er, vitamin D levels were below normal range in $70.3 \%$ of the patients receiving high flow oxygen therapy and in $71.2 \%$ of the patients using oseltamivir (Table 3).

\section{Discussion}

Viruses are the most common causes of respiratory tract infections in children. These viruses can lead to a clinical picture without any symptoms or to severe infections necessitating intensive care (13). RSV, which leads to both upper and lower respiratory tract infections, is the most common cause of respiratory tract infections in children worldwide $(9,10,13)$.
In recent studies, vitamin $\mathrm{D}$ deficiency, which also plays part in the development of immunity, has been reported to be of outmost importance in bronchiolitis that develop with RSV $(11,14)$. There are various studies in the literature investigating the relation between vitamin D and LRTI in children: however, studies on the subject matter discussed are very scarce in our country (11,15-17).

Various studies have shown that epithelial cells of the respiratory system can synthesize active vitamin $D$ and that this vitamin $D$ plays an important role in the production of antimicrobial peptides (cathelicidin/defensin) $(18,19)$. Cathelicidin 
aids in preventing the production of infections originating from bacteria and viruses (Mycobacterium tuberculosis, RSV) $(19,20)$. Therefore, it has been put forward that LRTI sensitivity and production show an increase in patients with low serum vitamin $D$ $(17,20)$.

In our study, median $25(\mathrm{OH})$ vitamin D was $22.5 \mathrm{ng} / \mathrm{mL}$ (3-58.7), and vitamin D insufficiency and vitamin $D$ deficiency were observed in $36.9 \%$ and $33.8 \%$ of the patients, respectively. In a study by Şişmanlar et al., it has been reported that in 19\% and $31 \%$ of the patients between the ages of 6 months- 5 years receiving $L R T I$ diagnosis for the first time had vitamin $D$ insufficiency and vitamin D deficiency, respectively. In our study, a higher-level vitamin $D$ insufficiency and deficiency was detected (16). Vitamin D is affected by many factors including age, sex, season, ethnic origin, socioeconomic level, exposure to sun light, prophylactic vitamin use, and diet $(15,17) .30 .8 \%$ of the patients in our study were refugees. While $25(\mathrm{OH})$ vitamin D level of Turkish citizens was $24.2 \mathrm{ng} / \mathrm{mL}$ (3-58.7), that of the refugees was $17.4 \mathrm{ng} / \mathrm{mL}(3.1-57,9)$, and hence it was seen that vitamin D level was lower in the refugees. It was speculated that nutrition deficiency and a more conservative clothing style that does not permit for exposure to sun light may have led to higher vitamin D deficiency and insufficiency. In addition, $13.1 \%$ of the patients under the age of 1 stated that they had not used prophylactic vitamin D. As expected, patients who had used prophylactic vitamin D were determined to have higher $25(\mathrm{OH})$ vitamin D level in comparison to the ones who had not.

Though > $30 \mathrm{ng} / \mathrm{mL}$ is considered normal for $25(\mathrm{OH})$ vitamin D level, it is still debatable which serum vitamin D level is effective in protecting the body against infections $(15,21)$. Various studies have indicated that $>30 \mathrm{ng} / \mathrm{mL}$ level is sufficient for the extra-osseous beneficial functions of vitamin $D(17,21)$. In our study, $70.7 \%$ of the patients had $<30 \mathrm{ng} / \mathrm{mL} 25(\mathrm{OH})$ vitamin D level. Low vitamin D levels were high.

There are few studies reporting that clinical severity scores of patients with acute bronchiolitis and recurrent attacks are associated with vitamin D deficiency and that patients with vitamin $D$ deficiency require intensive care and oxygen therapy more $(15,17,22)$. In a study by Inamo et al. where they have retrospectively assessed 28 patients aged 1-4 years, it has been claimed that low vitamin D level and clinical severity of LRTI can be associated (22). Similarly, Moreno-Solis et al. have reported in a study including 48 infants that low vitamin D levels in patients under the age of 1 is associated with the clinical severity of LRTD (17). On the other hand, in two studies conducted in Canada, a relation has not been found between vitamin $D$ levels and the clinical severity of $\operatorname{LRTD}(23,24)$. In a similar study carried out by lqbal et al., a relation between low $25(\mathrm{OH})$ vitamin $D$ levels and the clinical severity of LRTD has not been found in 38 patients with viral LRTD aged between 6 months and 12 years (25). In our study, a significant relation was not confirmed between the clinical severity of the infection and number of attacks and vitamin D deficiency. However, in $40.7 \%$ and $33.3 \%$ of the patients with severe clinical picture, vitamin $D$ deficiency and vitamin D insufficiency were confirmed, respectively. In $74 \%$ of the children with severe acute bronchiolitis, vitamin D level was below the normal range.

In a study by McNally et al. consisting children under the age of five, it has been reported that vitamin D deficiency is not associated with the clinical severity of LRTI; however, patients with vitamin $D$ deficiency require pediatric intensive care much more (23). In our study, $26.9 \%$ of the patients was followed in intensive care and $3.8 \%$ in mechanical ventilation.

Vitamin $D$ deficiency and insufficiency were detected in $45.7 \%$ and $31.4 \%$ of the patients requiring intensive care, respectively. So, $25(\mathrm{OH})$ vitamin D level was below normal range in $77.1 \%$ of the patients monitored in intensive care. Although there was no statistically significant difference between the 25 $(\mathrm{OH})$ vitamin D levels of patients monitored and not monitored in intensive care, it was considered that there was a distinct lowness.

In a limited number of studies in the literature, vitamin D deficiency has been reported to be a risk factor in LRTI development associated with RSV $(14,19,26)$. On the other hand, Mansbach et al. have not determined a relation between RSV and vitamin D in their study including 82 patients with 62 RSV infections (27). In another study, a relation has not been found between vitamin D and RSV bronchiolitis in 145 patients with RSV bronchiolitis under the age of 1 (11). In our study, RSV infection was confirmed in $55.3 \%$ of our patients, but a significant relation was not found between RSV and other viral agents and vitamin $D$ levels. Vitamin D deficiency and insufficiency were found in 40.3 and $36.1 \%$ of the patients with RSV, respectively.

High flow oxygen therapy used in treatment was implemented on $56.9 \%$ of the patients. In $70.3 \%$ of the patients receiving high flow oxygen therapy, $259(\mathrm{OH})$ vitamin D level was below the normal range. Despite not having found a statistically significant difference, it was observed that intense therapy was required by patients with low vitamin $D$ levels.

In a study by Avenell et al. conducted in adults, it has been reported that daily $800 \mathrm{U}$ vitamin $\mathrm{D}$ supplement decreases infection frequency by $10-15 \%$ (28). It has been indicated by Leis et al. in a study conducted with 197 children aged under 5 years that children taking $800 \mathrm{U}$ vitamin $\mathrm{D}$ develop four times less LRTI when compared to those taking vitamin D below $800 \mathrm{U}$ (29). Larkin et al. have recommended vitamin D support to children aged 5 years and under who are at risk of developing LRTI (30). 
Along with a limited number of studies investigating the relation between vitamin D and LRTI in our country, any other study exploring the relation between high flow oxygen therapy and vitamin D and viral agents (RSV and others) was not found in the literature $(15,16)$.

In spite of the fact that there was no relation between vitamin D level and RSV and other agents in our study, $25(\mathrm{OH})$ vitamin $D$ level of patients with severe bronchiolitis, patients who were monitored in intensive care and those who received high flow oxygen therapy was detected below the normal range. Since the effect of vitamin $D$ on infections, pulmonary function and immunity development is taken into consideration, we are of the opinion that prophylactic vitamin $D$ use should be well followed, $25(\mathrm{OH})$ vitamin D level should be tested in children with LRTI and that vitamin D treatment would be beneficial to patients in need. Moreover, further studies are needed to determine the ideal vitamin $D$ dosage that could prevent the infection to have a severe course clinically.

Ethics Committe Approval: Consent was obtained from the ethics committee of our hospital with the number 0058-599.

Informed Consent: Informed consent was obtained from the patients.

Peer-review: Externally peer-reviewed.

Author Contributions: Concept - ZY, MAT; Design - ZY, HÖ; Supervision - AUG, HÖ; Materials - HÖ, ZY; Data Collection - MAT, AUG; Analysis - ZY, MAT, Literature Review - ZY, MAT; Writing - ZY, MAT; Critical Review - MAT, AUG.

Conflict of Interest: No conflict of interest was declared by the authors.

Financial Disclosure: The authors declared that this study has received no financial support.

\section{References}

1. Heikkinen T. Respiratory viruses and children. 2016;(Suppl 72):S29-33.

2. Türk Toraks Derneği. Çocuklarda toplumda gelişen pnömoni tanı ve tedavi uzlaşı raporu 2009. (http://www.turkishthoracicjournal. com/ upload/documents/pdf_Toraksder_633.pdf). Erişim tarihi: 1.11.2018.

3. Camargo CA Jr, Ganmaa D, Frazier AL, Kirchberg FF, Stuart JJ, Kleinman $K$, et al. Randomized trial of vitamin D supplementation and risk of acute respiratory infection in Mongolia. Pediatrics 2012;130:e561-7.

4. Mansbach JM, Camargo CA. Bronchiolitis: lingering questions about its definition and the potential role of vitamin D. Pediatrics 2008;122:177-9.

5. Clancy N, Onwuneme C, Carroll A, McCarthy R, McKenna MJ, Murphy N, et al. Vitamin $D$ and neonatal immune function. J Matern Fetal Neonatal Med 2013;26:639-46.

6. Hansdottir S, MonickMM. Vitamin D effects on lung immunity and respiratory diseases. Vitam Horm 2011;86:217-37.

7. Cannell JJ, Vieth R, Umhau JC, Holick MF, Grant WB, Madronich S, et al. Epidemic influenza and vitamin D. Epidemiol Infect 2006; 134: 1129-40.
8. Türk Toraks Derneği. Akut bronşiyolit tanı ve tedavi uzlaşı raporu 2009. (http://www.turkishthoracicjournal. com/upload/documents/pdf_Toraksder_633.pdf). Erişim tarihi: 1.11.2018.

9. Sloots TP, Whiley DM, Lambert SB, Nissen MD. Emerging respiratory agents: new viruses for old diseases? J Clin Virol 2008;42:233-43.

10. Lamson D, Renwick N, Kapoor V, Liu Z, Palacios G, Ju J, et al. MassTag polymerase-chainreaction detection of respiratory pathogens, including a new rhinovirus genotype, that caused influenza-like illness in New York State during 2004-2005. J Infect Dis 2006;194:1398-402.

11. Beigelman A, Castro M, Schweiger TL, Wilson BS, Zheng J, Yin-DeClue H, et al. Vitamin D levels are unrelated to the severity of respiratory syncytial virus bronchiolitis among hospitalized infants. J Pediatric Infect Dis Soc 2015;4:182-8.

12. Holick MF. Vitamin D Status: Measurement, interpretation, and clinical application. Ann Epidemiol 2009;19:73-8.

13. Avcu G, Bal Şahbudak Z, Çiçek C, Vardar F. Solunum yolu virüs enfeksiyonu nedeni ile hastaneye yatan çocukların klinik ve epidemiyolojik olarak değerlendirilmesi. J Pediatr Inf 2017;11:111-5.

14. Belderbos ME, Houben ML, Wilbrink B, Lentjes E, Bloemen EM, Kimpen $J L$, et al. Cord blood vitamin D deficiency is associated with respiratory syncytial virus bronchiolitis. Pediatrics 2011;127:1513-20.

15. Sutcu Z, Sutcu M, Duru SN, Civilibal M, Elevli M. The role of serum vitamin $D$ level on lower respiratory tract infections in children. J Pediatr Inf 2016;10:54-9.

16. Şişmanlar T, Aslan AT, Gülbahar Ö, Özkan S. Çocuklarda vitamin D düzeyinin alt solunum yolu enfeksiyonları üzerine etkisi. Turk Pediatri Ars 2016;51:94-9.

17. Moreno-Solís G, Fernández-Gutiérrez F, Torres-Borrego J, Torcello-Gáspar R, Gómez-Chaparro Moreno JL, Pérez-Navero JL. Low serum 25-hydroxyvitamin D levels and bronchiolitis severity in Spanish infants. Eur J Pediatr 2015;174:365-72.

18. Hewison M. An update on vitamin D and human immunity. Clin Endocrinol 2012;76:315-25.

19. Liu PT, Stenger S, Li H, Wenzel L, Tan BH, Krutzik SR, et al. Toll-like receptor triggering of a vitamin D-mediated human antimicrobial response. Science 2006;311:1770-3.

20. Bozzetto S, Carraro S, Giordano G, Boner A, Baraldi E. Asthma, allergy and respiratory infections: the vitamin D hypothesis. Allergy 2012;67:107.

21. Henry HL Regulation of vitamin D metabolism. Best Pract Res Clin Endocrinol Metab 2011;25:531-41.

22. Inamo $Y$, Hasegawa $M$, Saito $K$, Hayashi $R$, Ishikawa $T$, Yoshino $Y$, et el. Serum vitamin $D$ concentrations and associated severity of acute lower respiratory tract infections in Japanese hospitalized children. Pediatr Int 2011;53:199-201.

23. McNally J, Leis K, Matheson LA, Karuananyake C, Sankaran K, Rosenberg $A M$. Vitamin $D$ deficiency in young children with severe acute lower respiratory infection. Pediatr Pulmonol 2009;44: 981-8.

24. Roth $D E$, Jones $A B$, Prosser $C$, Robinson JL, Vohra S. Vitamin D status is not associated with the risk of hospitalization for acute bronchiolitis in early childhood. Eur J Clin Nutr 2007;63:297-9.

25. Iqbal S, Mosenkis EV, Jain P, Wiles A, Lerner J, Benton AS, et al. Vitamin $D$ in pediatric inpatients with respiratory illnesses. Hosp Pediatr 2013;3:371-6.

26. Litonjua $A A$. Vitamin $D$ deficiency as a risk factor for childhood allergic disease and asthma. Curr Opin Allergy Clin Immunol 2012;12:179-85.

27. Mansbach JM, Piedra PA, Borregaard N, Martineau AR, Neuman MI, Espinola JA, et al. Serum cathelicidin level is associated with viral etiology and severity of bronchiolitis. J Allergy Clin Immunol 2012;130:1007-8. 
Yalaki et al.

20 Comparison of Viral Agents and Vitamin D Levels in

28. Avenell A, Cook JA, Maclennan GS, Macpherson GC. Vitamin D supplementation to prevent infections: a substudy of a randomised placebo-controlled trial in older people. Age Ageing 2007;36:574-7.

29. Leis KS, McNally JD, Montgomery MR, Sankaran K, Karunanayake C, Rosenberg AM. Vitamin D intake in young children with acute lower respiratory infection. Transl Pediatr 2012;1:6-14.
30. Larkin A, Lassetter J. Vitamin D deficiency and acute lower respiratory infections in children younger than 5 years: identification and treatment. J Pediatr Health Care 2014;28:572-82. 